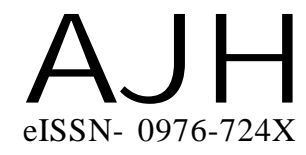

Received : 20.08.2015

Accepted : 30.11.2015
Author for correspondence :

Krishi Vigyan Kendra (S.K.NA.U.), Kumher, BHARATPUR (RAJASTHAN) INDIA

\title{
Impact of on farm testing on low yield of potato due to frost in Bharatpur district of eastern Rajasthan
}

\section{DILIP SINGH}

ABSTRACT : The Present study was carried out at Bharatpur district of Eastern Rajasthan during 2012-13, 2013-14 and 2014-15. Potato is one of the most important vegetable crops of the country. The development of the agriculture is primarily depends on the application of the scientific technologies by making the best use of available resources. One of the major constraints of traditional potato farming is low productivity because of non-adoption of advanced technologies to protect the crop from frost. To increase the production, productivity and quality of agricultural produce, on farm testing are being conducted at various farmer's field. All the recommended practices were provided to the selected farmers. The data related to the cost of cultivation, production, productivity, gross return and net return were collected as per schedule and analyzed. Result of the present study revealed that the application of concentrated $\mathrm{H}_{2} \mathrm{SO}_{4} @ 1.0 \mathrm{ml} / \mathrm{l}$ water on standing crop recorded the higher yield $(307.0 \mathrm{q} / \mathrm{ha})$ as compared to application of thio-urea @ 0.1 per cent on standing crop $(294.50 \mathrm{q} / \mathrm{ha})$ and control $(265.06 \mathrm{q} / \mathrm{ha})$. The percentage increase in the yield over control 15.82 was recorded.The technology gap in terms of productivity $(43.00 \mathrm{q} / \mathrm{ha}$.) were computed. The technology index values 12.28 per cent was recorded.The result of the study indicated the gap existed in the potential yield and demonstration yield is due to soil fertility and weather conditions. By conducting on farm testing of proven technologies of saving the crop by low temperature, yield potential of potato can be increased upto great extent. This will substantially increase the income as well as the livelihood of the farming community.

KEY WORDS : On farm testing, Control, Potato, Technology, Yield

HOW TO CITE THIS ARTICLE : Singh, Dilip (2015). Impact of on farm testing on low yield of potato due to frost in Bharatpur district of eastern Rajasthan. Asian J. Hort., 10(2) : 298-302. 